Finally, some of the work based on the experience of the operational research team, which visits foundries by invitation and provides advice on problems of production and layout, was shown, and included recommended suitable foundry layouts, improvements in production flow lines, the correct use of patterns and moulding equipment, and data on output and costs.

J. G. Pearce

\section{ORGANIZATION OF THE METEOROLOGICAL OFFICE}

$\mathrm{N}$ a written answer in the House of Commons on June 28, the Secretary of State for Air, Mr. G. Ward, said that the Committee appointed in 1955 under Lord Brabazon to review the organization of the Meteorological Office in relation to current and future requirements saw no reason to question the wisdom of the decision to entrust responsibility for the State meteorological service to the Air Ministry, and was satisfied that the close association of the Meteorological Office with aviation since 1919 had been mutually advantageous. The Committee considered that the present standing of the Meteorological Office as a scientific institution was high, and that users had great confidence in the services provided. The Committee welcomed the work being done by the research staff in the development of numerical methods of forecasting, and the decision to install an electronic computer at the Central Forecasting Office. It considered that greater precision in local forecasting might be achieved by more detailed study of local weather characteristics, coupled with the use of radar scanners. The development of a combined headquarters at Bracknell should eliminate the present loss of effort due to dispersal of the Office.

As a result of the Committee's recommendations, the Meteorological Office had been reorganized under a director-general with two sections, concerned with forecasting and services and with research, each under a chief scientific officer, and a third section, under an assistant secretary, with administration and general duties. Measures approved as a result of the report, including an increased number of higher level posts, and an increase in the number of senior appointments open to the experimental officer class, would improve the prospects available to both the experimental and the scientific officer classes. The Committee expressed the hope that it would be possible to bring home to the universities the challenge which meteorology presented to the imagination of the first-class physicist or mathematician.

The Committee suggested no changes in the constitution or terms of reference of the Meteorological Research Committee or in the division of the research programme between the Meteorological Office and the universities, but recommended that the arrangemont under which a separate grant is made to the Royal Society for fundamental research should be reviewed at the end of the current five-year period and that grants for research emanating from the Air Ministry should thereafter normally be channelled through the Meteorological Research Committe日. This recommendation was still under discussion. The Committee also recommended a system of research grants for postgraduate study in meteorology, and the Department of Scientific and Industrial Research was willing to consider awards under the scheme it administers.
The Committee also recommended a review of the man-power requirements for aviation services. The requirements of civil aviation were being reviewed in conjunction with the Ministry of Transport and Civil Aviation. Local forecasting units were desirable for other purposes, particularly in agricultural and horticultural districts, but a more detailed examination was required before any pattern of development could be approved. The Minister said that he had accepted the Committee's recommendation that the existing Meteorological Committee should be replaced by an advisory committee of not more than five members, all of whom would be outside the Government service. The new Committee would consist of an independent chairman, and four members, including the chairman of the Meteorological Research Committee ex-officio and another scientist, appointed after consultation with the president of the Royal Society, and normally two laymen. Lord Hurcombe had accepted the invitation to become chairman of the new Committee, which would be required to keep under review the progress and efficiency of the Meteorological Office and the broad lines of its current and future policy, the general scale of effort and expenditure devoted to the Meteorological Office, and the contacts between the Office and those using its services.

\section{WATER RESOURCES OF GREAT BRITAIN}

$T$ THE publication of the Surface Water Year Book $1954-55^{*}$ is a further welcome addition to the growing body of hydrological knowledge for Great Britain. The first four Surface Water volumes dealt with the periods 1935-36, 1936-37, 1937-45 and 1945-53 : since that date the volume has been appearing annually and the time-lag in publication has been steadily reduced.

There has been an increase from 102 gauging stations in 1953-54 to 116 gauging stations in this latest volume; but some changes have been made in the presentation of the statistics for 1954-55 in order to reduce both the size and the cost of the volume. The daily mean discharge tables have been omitted, while hydrometric records of 'reservoired areas' have, been summarized on a single page. The station descriptions have been rearranged and condensed, and the surface geology particulars omitted. Complete records and details are, however, available for consultation at the Surface Water Survey Centre.

While progress is thus being made in the collection and dissemination of these basic hydrological data concern is still being expressed at the lack of a muchneeded water policy for Great Britain. A notable debate in the House of Lords on May 29 surveyed the steadily increasing consumption of water per day, and also the rising consumption of water per head per day throughout the country. Emphasis was laid upon the very great and continuing increase in the industrial use of water over the past two decades, to which must be added the demand likely to arise in agriculture with the application of summer irrigation methods. Some areas now face the prospect of permanent water shortages even under normal

- Ministry of Housing and Local Government. and Scottish Office. The Surface Water Year-Book of Great Britain 1954-55. (Hydrometric statistics for British Rivers, together with related rainfalls, for the yearended 30 th September, 1955.) Pp. xi +54. (London: H.M.S.O. 1957.) 15s. net. 
conditions, while a slight drought will rapidly exhaust available reserves and bring industry and agriculture to a standstill in other localities.

Replying for the Government, Lord Mancroft stated that the subcommittees appointed by the Central Advisory Water Committee of the Ministry of Housing and Local Government in 1955 would be pressed to complete their investigations as a matter of urgency. The Government hoped for a reduction in the large number of water undertakings in the country (nearly 1,300 ) by voluntary amalgamations. It was also studying the whole question of the organization of hydrological research, as one of the chief difficulties in the present situation was the lack of reliable information. No authoritative figures of the rate of increase of water consumption, nor of the available total resources, existed. It was fully realized that not enough information was yet available to assess accurately exactly how serious the problem was likely to be, but "Her Majesty's Government are most earnestly and objectively going into this whole problem" as the urgent need for a more precise assessment of the situation had been recognized.

W. G. V. BALCHIN

\section{THE WELLCOME TRUST}

\section{REPORT FOR 1937-56}

$\mathrm{T}$

HE first report of the Wellcome Trust, recently issued*, covers the first twenty years of the Trust's activities, during 1937-56. Its major interest is in the general survey of the origin and activities of the Trust, which occupies the greater part of the report, including an appreciation of the work of the founder, the late Sir Henry S. Wellcome. There are a classified list of grants and a clear statement of the policy pursued by the trustees, with appended lists of recipients of various medals and prizes awarded by or on behalf of the Trust, and of publications from the Wellcome Trust Research Laboratories or subsidized by the Trust. During the period the trustees have made grants totalling $£ 313,883$ for medical research, museums and libraries, and have allocated $£ 64,053$ to assist research in the history of medicine. $\mathfrak{1 4 8 , 3 3 5}$ has been spent on completing Sir Henry Wellcome's "Archæological Enterprises", and on publishing the findings of these and a related independent study, while $£ 4,105$ has been provided for Wellcome medals and prizes. To August 31, 1956, a total of $£ 739,788$ had been provided for medical and veterinary research, of which $£ 300,000$ was allocated in respect of building and other projects not yet effective. Of this sum, $£ 193,090$ was for research chairs, $£ 321,700$ for building, adaptation and equipment of research laboratories, £52,215 for special equipment, and $£ 7,699$ for miscellaneous travel grants.

For reasons given in the report the trustees had to postpone for more than ten years the full development of the main activities of the Trust, and in the meantime they recognized that the archæological enterprises which Sir Henry Wellcome had been supporting at Jebel Moya and other sites in the Sudan, and at Tell ed-Duweir (Lachish) in Palestine, had prior claim. The results of the former work at Jebel Moya were published for the trustees by the Oxford University Press in 1949, and those of the explorations at the neighbouring sites of Abu Geili,

* The Wellcome Trust. First Report covering the period 1937* The Wellcome Trust. First Report covering the
1956. Pp. 86. (London: The Wellcome Trust, 1957.)
Segadi and Dar el Mek in a later volume, while after excavation at Lachish was terminated by the outbreak of war in 1939 , the results were prepared for publication by Miss $\mathrm{O}$. Tufnell.

At an early stage, however, the trustees considered the choice of areas of research in medicine and related sciences in which they could plan to use the funds at their disposal to serve the objects of the Trust: the advancement of research bearing on medicine, surgery, pharmacy and allied subjects, and the establishment, endowment and maintenance of research museums or libraries in that field. 1hey took the view that these funds would be used to the best advantage if not too widely diffused, and if their activities were planned so as to be complementary to those of other funds with similar aims. Accordingly, they decided to give preference to those subjects which had attracted Sir Henry Wellcome's own active interest and so to give priority to work in pharmacy and pharmacology, veterinary medicine and tropical medicine. While continuing to provide funds for the several medals and prizes established by Sir Henry himself, it is not a part of the trustees' present policy to consider the creation of other such awards.

In 1938, the trustees accepted full responsibility for the laboratory at Thessaloniki, where Dr. H. Foy had been engaged on research in malaria, and the laboratory was named the Wellcome Trust Research Laboratory, Thessaloniki. In 1953, the appointment of Dr. Foy was given academic permanence. Later, the laboratory was extended, and when continuation of the work at Thessaloniki became impossible at the end of 1940, the work was transferred to the South African Institute of Medical Research, Johannesburg, until work could be resumed at Thessaloniki in 1945-48. With the reduction of the prevalence of malaria to very small proportions in consequence of the insecticides discovered during the War, it was again decided to close the Thessaloniki laboratory, and since 1949 Dr. Foy and his co-workers have been working, with Nairobi as base, on a programme now including the study of nutritional and other forms of anæmia widely prevalent in the tropics, as well as the distribution of the sickle-cell trait. In 1942, the trustees made a grant of $£ 20,000$ for further research on the development of methods for drying human blood-plasma and serum and for the purchase of the necessary plant, and between February 1943, when the plant came into operation, and September 1945, when it closed down, this plant provided stable dried plasma and serum to meet the whole of the requirements of the Royal Navy and of the civilian population of Britain, and a proportion of those of the Army and of the Royal Air Force.

A grant of $£ 44,000$ was made in 1945 for the creation of the Wellcome professorship of clinical tropical medicine in the London School of Hygiene and Tropical Medicine, and one of $£ 74,000$ in 1946 for the endowment of a full-time Wellcome professorship of pharmacology in the School of Pharmacy, University of London. Grants of $£ 18,000$ were made to the Animal Health Trust and of upwards of $£ 10,000$ to the Pharmaceutical Society for research fellowships, and $£ 15,000$ was awarded for various research fellowships in such subjects as biochemistry-while in 1956 a Wellcome research professorship of anæsthesiology was established at McGill University with a total grant of about $£ 50,000$; together with a Wellcome associate research professorship at the University of Pennsylvania, with a grant of about $£ 25,000$. 